\title{
Papillary Renal Cell Carcinoma
}

National Cancer Institute

\section{Source}

National Cancer Institute. Papillary Renal Cell Carcinoma. NCI Thesaurus. Code C6975.

Also known as chromophil carcinoma, it represents a minority of renal cell carcinomas. It can be hereditary or sporadic. The sporadic papillary renal cell carcinoma is characterized by trisomy of chromosomes 7, 16, and 17, and loss of chromosome $Y$. The peak incidence is in the sixth and seven decades. It is classified as type 1 or 2, based on the cytoplasmic volume and the thickness of the lining neoplastic cells. The prognosis is more favorable than for conventional (clear cell) renal cell carcinoma. -- 2003 